DOI: https://doi.org/10.31933/dijms.v2i2 Received: 12 August 2020, Revised: 15 October 2020, Publish: 25 November 2020

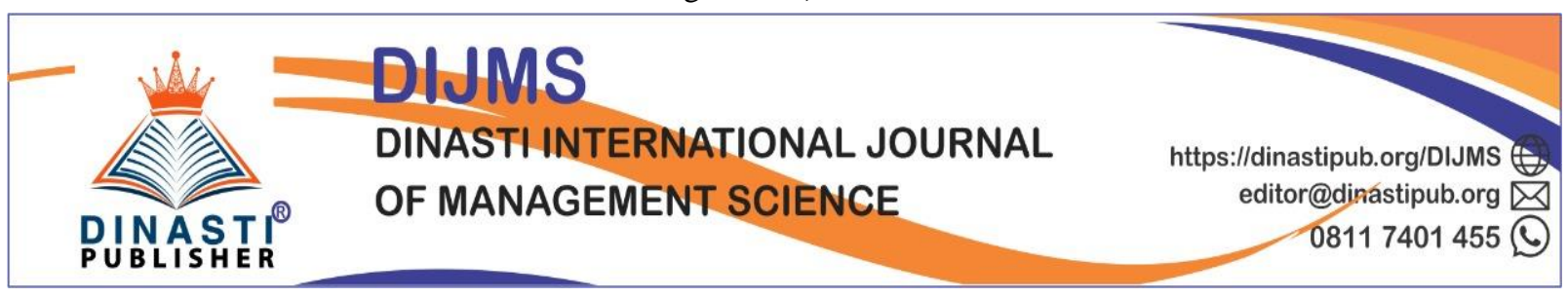

\title{
THE INFLUENCE OF WORKLOAD, WORK ENVIRONMENT AND TEAMWORK AGAINST TURNOVER INTENTION WHICH MEDIATED THROUGH ORGANIZATION COMMITMENT (CASE STUDY ON EMPLOYEE AT PT. MULTIPRO JAYA PRIMA)
}

\author{
Nurul Hidayah ${ }^{1}$, Chaerudin ${ }^{2}$ \\ ${ }^{1)}$ Mercu Buana University, Jakarta, Indonesia, hidayahnurul1015@gmail.com \\ ${ }^{2)}$ Mercu Buana University, Jakarta, Indonesia, chaerudin18@gmail.com
}

\section{Corresponding Author: Nurul Hidayah}

Abstract: This research aimed to measure and analyze those influence which came from workload, work environment and teamwork on turnover intention through organization commitment. This research include in quantitative research. Population and sample in this research were all employee at PT. Multipro Jaya Prima, with total 84 employees. The sample gathered technique used saturated sampling. The research data used linear regression. The results from t-test for variables such as workload, work environment, and teamwork had an influence toward turnover intention either partially or simultaneously.

Keywords: Workload, work environment, teamwork, turnover intention, organization commitment.

\section{INTRODUCTION}

The success from company cannot be separated from quality of its human resources to be able to show quality performance so it can make the company survive or even provide benefits for company. One of that factor which affects performance is work load, if the workers ability is higher than work demands, it will triggered numb feeling tho their performance is good, in the other hand, if workers skills is lower than work demands, and excessive fatigue will come out. Beside that, work environment as a place for employee to work at company as well as a place to interact with each other, a bad work environment could impact those employee activities at work, otherwise comfortable work environment will create Pleasant situation for employee at work.

To create a comfortable work environment it requires teamwork. If company does not have strong cooperation between one division and another, the results of its work will be unsatisfaction and inefficient (on time). beside that, teamwork and organization commitment 
should be growth and exist on each employee to survive in organization environment. Employees who are committed to stay in organization would find comfort, if employee already feel comfort, the workload feels lighter with teamwork.

PT. Multipro Jaya Prima is a company which engaged in hardware distribution or sales of IT equipment that located in North Jakarta, detailed on Pluit area and this company is an official partner of well-known brands, such as Dell, HP, Lenovo ,Sisco, APC those all brands are well known to consumers. The phenomenon that occurs in this company is Lots of employee workloads. The high target of company makes employees feel that they have an excessive workload and in the end they do not reach the target that has been set, which is in contrast to average overtime which has increased every year.

Table 1. Company Targets and Overtime Average

\begin{tabular}{|c|c|c|c|}
\hline Year & Target & Realization & Overtime Average \\
\hline 2017 & 211.000 .000 .000 & 200.800 .968 .000 & 25 Hour \\
\hline 2018 & 211.100 .000 .000 & 200.119 .200 .000 & 25.7 Hour \\
\hline 2019 & 211.200 .000 .000 & 210.994 .782 .000 & 29 Hour \\
\hline
\end{tabular}

Source: PT Multipro Jaya Prima (2020)

Then another phenomenon is problem in mechanical division. in this division, there are also bad term between sales and the mechanic team which can stumble to company sales because of customers disappointment towards mechanics who can not finish the work on time when did their work This resulted in delays in time that agreed at the beginning of contract.

Table 2. Time Schedule Project

\begin{tabular}{|c|l|l|l|}
\hline No & \multicolumn{1}{|c|}{ Description } & \multicolumn{1}{|c|}{ Sales time plan } & \multicolumn{1}{c|}{ Raelity } \\
\hline 1 & APC brand's UPS service jobs & 3 Mont & 5 Month - Finish \\
\hline 2 & Raft mount's installed work & 2 Mont & 4 Month - Finish \\
\hline 3 & $\begin{array}{l}\text { Windows installation / installation } \\
\text { work, hard disk, memory for 4 servers }\end{array}$ & 1 Week & 3 Week \\
\hline 4 & 42U server rack assembly work & 3 Month & 5 Month \\
\hline 5 & The work of making Licanse Fortinet & 1 Month & 2 Month \\
\hline 6 & HPE server service jobs, Dell & 2 Month & 3 Month \\
\hline
\end{tabular}

Source: PT Multipro Jaya Prima (2020)

The problems that occur based on results from HRD interviews with researchers, it is known that there are negative factors that could reduce employee performance due to material aprovel that is too long from original distributor because there are several mechanical devices that must be taken directly from the center, decreasing those desire from employees to achieve work performance. Lack of punctuality in completing work, this could lead to sub-optimal performance. To be able to convince researchers to carried out this research, the researchers did pre-survey first towards 42 respondents in sales and mechanic divisions. From the presurvey results, it was found that workload, teamwork, work environment and organization commitment are factors that strongly suspected to influenced employee performance that is less than optimal, which ultimately results in turnover intention. 
Based on background above, researchers were interested in conducting research on employees at PT. Multipro Jaya Prima to prove that how further the level of workload, teamwork affects organization commitment and its implications against turnover intention. Therefore, the researcher wants to examined: "The Influence of Workload, Work Environment and Teamwork against Turnover Intention which Mediated through Organization Commitment (Case study on employee at PT. Multipro Jaya Prima)".

\section{LITERATURE REVIEW}

\section{Workload}

Tarwaka (2015:104) defined that workload as a level of loading that is too high allowing excessive energy use and created "overstres", in the other hand, the optimum loading intensity between the two extreme limits and of course differs from one individual to another. Furthermore, Tarwaka (2015:105) stated that there has two factors that influence workload, such as : external factors (tasks, work organization, work environment) and internal factors (somastic factors and psychological factors).

\section{Work Environment}

Work environment could affect employee emotional. If an employee Pleasant with their work environment, then the employee would feel comfort at their workplace, carrying out their activities so working time would use effectively. Sedarmayanti in Irvianti (2015) said that work environment of company could be measured through physical work environment and non-physical work environment.

\section{Teamwork}

According to Wibowo in Rakhmawati (2014), in team-based organizations, the achievement of organizational performance is hugely determined by performance of a team which consisted of a group of people with different cultural backgrounds and varying competencies, therefore success of team is hugely caused by their ability to work together. Furthermore, Tjosvold et al in Rakhmawati (2014) stated that teamwork can be measured through collaboration and wholeness.

\section{Organization Commitment}

According to Kaswan in Sutrisno and Chaeruddin (2020) organization commitment was defined as an attitude that reflects employee loyalty to organization and continuous process where organization members expressed their concern to organization and its success and its continuously progress. Meanwhile, Robbins in Melky (2015) defined that organization commitment, such as the level of which an employee sides with particular organization and its goals. Furthermore, Allen and Mayer in Yosua Melky (2015) explained that there are 3 measurement scales for organization commitment, such as affective commitment, normative commitment and sustainable commitment. 


\section{Turnover Intention}

Zeffane in Halimah (2016) quoted that intention is an motive that arises from an individual to do something. Meanwhile, turnover is quit

Job Voluntarily stopping from their place of work or moving from one workplace to another. Thus, turnover intention is the tendency or intention of employees to quit their job. Furthermore, Mobley et al in Halimah (2016) stated that turnover intention could be measured through: thinking of quitting, intention to search for alternatives and intention to quit.

\section{Previous Research}

Research which conducted by Arifin and Alhabsji (2016) stated that workload had significant positive influence against organization commitment. Research which conducted by Subagyo (2014) stated that work environment had significant positive influence towards organization commitment. Research that carried out by Hanaysha (2016) stated that teamwork had significant positive impact on organization commitment. Research conducted by Luz (2016) said that organization commitment had significant negative influence over turnover intention. Prior research that conducted by Pradita and Satrya (2019) stated that workload had no impact on turnover intention. Previous research conducted by Dhurupa, et., Al. (2015) which states that teamwork had significant negative influence on turnover intention.

\section{Theoretical Framework}

Based on theoretical description that previously described, a model for this research framework could be made as in this following figure.

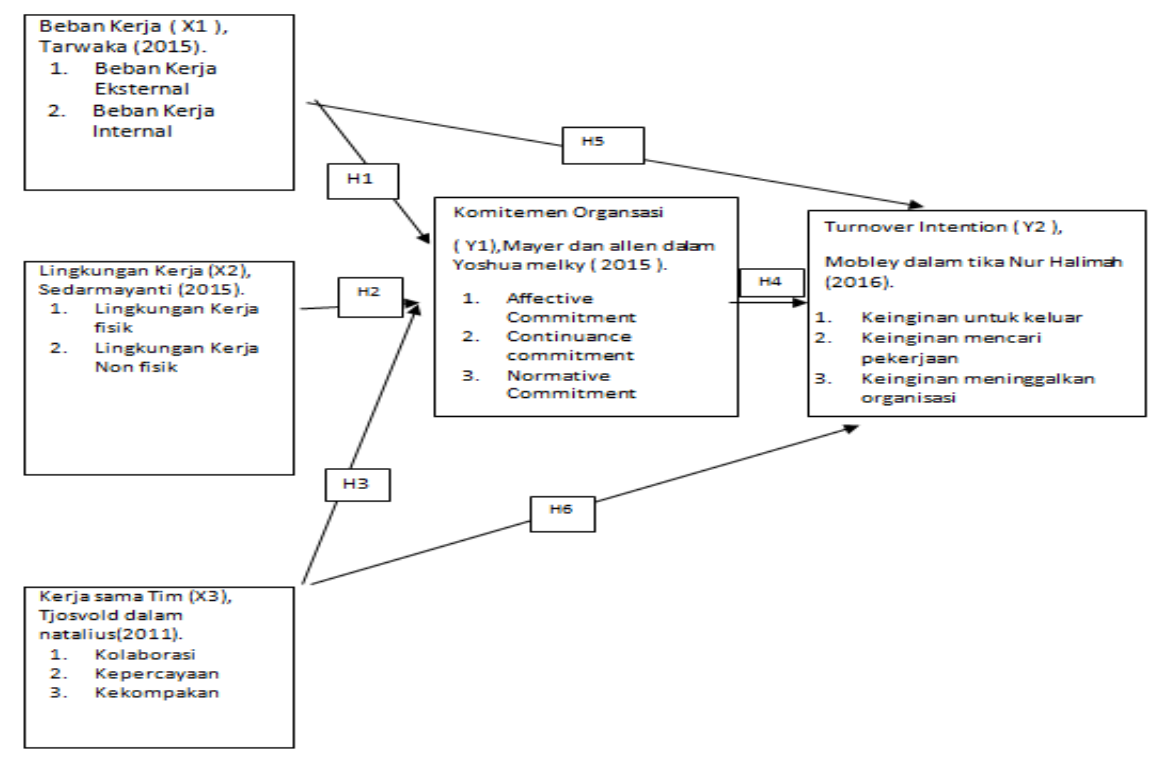

Figure 1. Theoretical Framework

\section{Research Hypothesis}

Hypothesis in this research were: 1) There had an influence from workload towards organization commitment at PT. Multipro Jaya Prima; 2) There had an influence of work environment to organization commitment at PT. Multipro Jaya Prima; 3) There had influence 
from teamwork on organization commitment at PT. Multipro Jaya Prima; 4) There had influence from organization commitment towards turnover intention at PT. Multipro Jaya Prima; 5) There had an effect from workload to turnover intention at PT. Mulipro Jaya Prima; and 6) There had influence from teamwork on turnover intention at PT. Multipro Jaya Prima.

\section{RESEARCH METHODS}

The design of this research used a causal descriptive study. This research aims to determine those influence from workload, work environment and teamwork towards turnover intention which mediated by organization commitment at PT. Multipro Jaya Prima North Jakarta. Population and sample of this research were employee at PT. Iskaba Pratama South Jakarta, by numbered of 84 employees in mechanical, sales, admin and warehouse teams. sampling technique used nonprobability sampling where data analysis method used Component or Variance Based Structural Equation Model while the data processed by Partial Least Square (Smart-PLS) version 3.0 PLS program.

\section{RESULT AND DISCUSSION}

\section{Outer Model Measurement}

The Analysis from the outer model in this research used convergent validity, composite reliability and Cronbach's Alpha. According to the test results by convergent validity, there are 7 indicators (BK1, BK6, LK6, KT4, KO3, KO4, TI5) that have loading factor value less than 0.50. Therefore, these indicators would be removed from the model. After re-calculating, it was recognized that all indicators met the convergent validity because their loading factor value above 0.50 and it could be concluded that all indicators in this research were valid.

Table 3.Test Results of Convergent Validity (modification)

\begin{tabular}{|c|c|c|c|}
\hline Variable & Indicator & $\begin{array}{l}\text { Loading } \\
\text { Factor }\end{array}$ & Information \\
\hline \multirow{4}{*}{ Workload } & BK2 & 0.709 & Valid \\
\hline & BK3 & 0.659 & Valid \\
\hline & BK4 & 0.904 & Valid \\
\hline & BK5 & 0.865 & Valid \\
\hline \multirow{5}{*}{$\begin{array}{c}\text { Work } \\
\text { Environment }\end{array}$} & LK1 & 0.561 & Valid \\
\hline & LK2 & 0.700 & Valid \\
\hline & LK3 & 0.855 & Valid \\
\hline & LK4 & 0.866 & Valid \\
\hline & LK5 & 0.856 & Valid \\
\hline \multirow{5}{*}{ Teamwork } & KT1 & 0.709 & Valid \\
\hline & KT2 & 0.731 & Valid \\
\hline & KT3 & 0.724 & Valid \\
\hline & KT5 & 0.664 & Valid \\
\hline & KT6 & 0.889 & Valid \\
\hline \multirow{7}{*}{$\begin{array}{l}\text { Organizational } \\
\text { Commitment }\end{array}$} & KO1 & 0.805 & Valid \\
\hline & $\mathrm{KO} 2$ & 0.616 & Valid \\
\hline & KO5 & 0.626 & Valid \\
\hline & KO6 & 0.643 & Valid \\
\hline & KO7 & 0.811 & Valid \\
\hline & KO8 & 0.830 & Valid \\
\hline & KO9 & 0.645 & Valid \\
\hline \multirow{8}{*}{$\begin{array}{l}\text { Turnover } \\
\text { Intention }\end{array}$} & TI1 & 0.719 & Valid \\
\hline & TI2 & 0.812 & Valid \\
\hline & TI3 & 0.709 & Valid \\
\hline & TI4 & 0.834 & Valid \\
\hline & TI6 & 0.692 & Valid \\
\hline & TI7 & 0.697 & Valid \\
\hline & TI8 & 0.753 & Valid \\
\hline & TI9 & 0.784 & Valid \\
\hline
\end{tabular}


After examined this construct validity, further test would be construct reliability test. Based on test results, it could be seen that composite reliability and cronbach's alpha shows value $>0.7$, meaning that value from each instrument was reliable.

Table 4. Reliability Test Result

\begin{tabular}{|l|c|c|}
\hline \multicolumn{1}{|c|}{ Variable } & $\begin{array}{c}\text { Cronbach's } \\
\text { Alpha }\end{array}$ & $\begin{array}{c}\text { Composite } \\
\text { Reliability }\end{array}$ \\
\hline Workload & 0.792 & 0.868 \\
\hline Teamwork & 0.813 & 0.871 \\
\hline $\begin{array}{l}\text { Organizational } \\
\text { Commitment }\end{array}$ & 0.838 & 0.879 \\
\hline Work Environment & 0.828 & 0.883 \\
\hline Turnover Intention & 0.890 & 0.912 \\
\hline
\end{tabular}

\section{Inner Model Measurement}

The structural model was evaluated by R-square for the dependent construct, the StoneGeiser Q-Square test for relevant predictive. Based on R-square test result, the R-square value for organization commitment variable was 0.887 which could be interpreted that organization commitment construct variability which can be explained by workload variability, work environment, and teamwork was 88.7 while the R-square value for variable Turnover intention was 0.686 which could be interpreted that turnover intention construct variability which could be explained by workload variability, teamwork, and organization commitment was $68.6 \%$.

Tabel 4. R-Squared Coefficients

\begin{tabular}{|l|c|}
\hline \multicolumn{1}{|c|}{ Variable } & R Square \\
\hline Organizational Commitment & 0.887 \\
\hline Turnover intention & 0.686 \\
\hline
\end{tabular}

Besides, it shows the R-Square value, the model was also evaluated by the predictive relevance of Q-square for constructive model. Q-square measures how well the observed value was generated by model and also its parameter estimates. The numbered of Q2 had range value of $0<\mathrm{Q} 2>1$, where the closer to 1 means the model was getting better. Based on estimation results, it is known that Q-Square value was 0.964. This shows that the large diversity of research data that could be explained from this research was $96.4 \%$ and the remaining 3.6\% was explained by other factors outside this research.

In PLS test of each relationship was carried out by simulation of boostrapping method from this sample, while the results from boostrapping in this research could be seen in Table 4 below. 
Table 5. Path Coefficient and P-Values

\begin{tabular}{|l|c|c|c|c|c|}
\hline & $\begin{array}{c}\text { Original } \\
\text { Sample } \\
(\mathbf{O})\end{array}$ & $\begin{array}{c}\text { Sample } \\
\text { Mean } \\
(\mathbf{M})\end{array}$ & $\begin{array}{c}\text { Standard } \\
\text { Deviation } \\
\text { (STDEV) }\end{array}$ & $\begin{array}{c}\text { T } \\
\text { Statistics }\end{array}$ & $\begin{array}{c}\text { P } \\
\text { Values }\end{array}$ \\
\hline $\begin{array}{l}\text { Workload } \rightarrow \text { Organizational } \\
\text { Commitment }\end{array}$ & 0.413 & 0.442 & 0.119 & 3.477 & 0.001 \\
\hline $\begin{array}{l}\text { Work Environment } \rightarrow \\
\text { Organizational Commitment }\end{array}$ & 0.307 & 0.306 & 0.148 & 2.078 & 0.002 \\
\hline $\begin{array}{l}\text { Teamwork } \rightarrow \text { Organizational } \\
\text { Commitment }\end{array}$ & 0.602 & 0.572 & 0.097 & 6.177 & 0.000 \\
\hline $\begin{array}{l}\text { Organizational Commitment } \rightarrow \\
\text { Turnover intention }\end{array}$ & -0.515 & -0.486 & 0.190 & 2.793 & 0.000 \\
\hline Workload $\rightarrow$ Turnover intention & 0.233 & 0.237 & 0.120 & 1.935 & 0.058 \\
\hline $\begin{array}{l}\text { Teamwork } \rightarrow \text { Turnover } \\
\text { intention }\end{array}$ & -0.511 & -0.582 & 0.185 & 2.765 & 0.000 \\
\hline
\end{tabular}

Based on Table 5, so it could be said that:

1) Workload variable had significant influence towards organization commitment variable with T Statistics value $>1.96$.

2) Work environment variable had significant influence towards organization commitment variable with $\mathrm{T}$ Statistics value $>1.96$.

3) Teamwork variable had significant impact over organization commitment variable with $\mathrm{T}$ Statistics value $>1.96$.

4) Organizational commitment variable had significant impact on turnover intention variable with T Statistics value > 1.96 .

5) Workload variable had none significant impact towards turnover intention variable with $\mathrm{T}$ Statistics value $<1.96$.

Teamwork variable had significant affect on turnover intention variable with $\mathrm{T}$ Statistics value $>1.96$.

\section{Discussion}

Based on results from this research, workload had positive and significant influence towards organizational commitment, meaning that workload had similiar direction influence on organizational commitment or in other words if the workload increase, there will be an increase in organization commitment aswell and statistically had significant impact. The results from this research were in line with prior research that conducted from Arifin and Alhabsji (2016) which stated that workload had significant positive impact towards organization commitment.

Based on the results from this research, work environment had positive and significant influence on organization commitment, meaning that work environment had unidirectional influence towards organization commitment or in other words, if work environment in company is good, there will be an increase in organizational commitment and statistically significant impact. The results from this research were in line with prior research that conducted by Subagyo (2014) meaning that work environment had significant positive impact towards organization commitment. 
Based on the research results, it said that teamwork had positive and significant influence towards organization commitment, meaning that teamwork had unidirectional influence towards organization commitment, or in other words, if teamwork is well established, it will increase organization commitment and have statistically significant impact. The results from this research were in line with previous research which conducted by Hanaysha (2016) it stated that teamwork had significant positive impact on organization commitment.

Based on research results, organization commitment had negative and significant influence on turnover intention, meaning that organization commitment had non-directional influence on turnover intention or in other words, if organization commitment is low, it will increase turnover intention and statistically had significant effect. This results were in line with previous research that conducted by Luz (2016) which stated that organizational commitment had significant negative influence towards turnover intention.

Based on the results of this research, tells that workload had no impact towards turnover intention, meaning that workload does not have an influence towards turnover intention or in other words, if high or low workload does not affect turnover intention and statistically have no significant effect. This results were in line with prior research by Pradita and Satrya (2019)which said that workload had no influence over turnover intention.

Based on results from this research, it said that teamwork had negative and significant impact against turnover intention, meaning that teamwork had non-directional reaction on turnover intention or in other words, if teamwork is not well established, it will increase turnover intention and statistically had significant effect. This results were in line with previous research by Dhurupa, et., al. (2015) which said that teamwork had significant negative impact on turnover intention.

\section{CONCLUSION AND SUGGESTION}

\section{Conclusion}

Based on the research which conducted on employees at PT. Multipro Jaya Prima, this following conclusions could be drawn as its follows 1) Workload had significant positive influence over organization commitment at PT. Multipro Jaya Prima; 2) Work environment had significant positive impact towards organization commitment at PT. Multipro Jaya Prima; 3) Teamwork had significant positive impact towards organization commitment at PT. Multipro Jaya Prima; 4) Organization commitment had significant negative influence towards turnover intention at PT. Multipro Jaya Prima; 5) Workload had none influence on turnover intention at PT. Multipro Jaya Prima; and 6) Teamwork had significant negative impact over turnover intention at PT. Multipro Jaya Prima.

\section{Suggestion}

1) According to conclusions above, those several suggestions can be put into consideration for PT. Multipro Jaya Prima: 1) The company should give the job, it is better if it provides time limit in according to the level of difficulty of the work, so employee do not rush and make wrong decisions; 2) Bosses should provide motivation to their employees, such as giving yells in morning before starting activities; 3) Companies should accustomed their employee 
to work in teams with mutual trust among team mates; 4) The company should created a commitment according to work level of employee, so employee had desire to spend all their career life in this company; and 5) company should adjust the benefits which given to employee to reduce employee intention to leave, such as providing compensation according to real performance achievement.

\section{REFERENCES}

Dhurup, M., et., al. (2016). Finding Synergic Relationships in Teamwork, Organizational Commitment and Job Satisfaction: a Case Study of a Construction Organization in a Developing Country. Prodecia Economics and Finance, 35, 485-492.

Luz, C. M. D. R. (2018). Organizational Commitment, Job Satisfation and Their Possible Influences on Intent To turnover. Revista de Gestao, 25(1).

Melky, Y. (2015). Pengaruh Kepuasan Kerja dan Komitmen Organisasi Terhadap Intensi Pindah Kerja Turnover Intention Karyawan di PT. Rezeki Abadi Sakti Samarinda: eJournal Psikologi, 3(3): 694-707.

Halimah, T. N. ( 2016 ). Pengaruh Job insecurity, Kepuasan kerja dan Lingkungan Kerja Terhadap Turnover Intenton Pramuniaga di Glael Supermarket. Journal of Management, 2(2).

Hanaysha, J. (2016). Examining the Effects of Employee Empowerment, Teamwork, and Employee Training on Organizational Commitment. Prodecia-Social and Behavioral Sciences, 229, 298-306.

Pradita, N. N., dan Satrya, A. (2019). The Influence of Empowerment and Workload on Turnover Intention trough the Mediation of Emotional Exhaustion on Indonesian Garment Workers. International Journal of Scientific \& Engineering Research, 10(1).

Rakhmawati, D. (2014 ). Pengaruh Gaya Kepemimpinan Transformal, Kepercayaan, dan Kerjasamatim Terhadap Komitmen Organisasi Untuk Meningkatkan Kinerja Karyawan. Media Ekonomi dan Manajemen, 29(1).

Irvianti, S. D. L. (2015). Analisis Pengaruh Stres Kerja, Beban Kerja, dan Lingkungan Kerja terhadap Turnover Intention Karyawan pada PT XL Axiata. Binus Bussines Review, $6(1), 117-126$.

Subagyo, A. (2014). Pengaruh Lingkungan Kerja dan Self Eficacy Terhadap Komitmen Organisasional Dosen Politeknik Negeri Semarang. Majalah Ilmiah Pengembangan Rekayasa dan Sosial, 10(1).

Sutrisno, D. dan Chaeruddin. (2020). The Reaction Over Employees Performance Through Organizational Culture, and Organizational Commitment Variables Whom Mediated by Organizational Citizenship Behaviour and Its Implications at PT Sharprindo Dinamika Prima. Dinasti International Journal, 1(6), 863-877.

Tarwaka. (2015). Ergonomi Industri Dasar-Dasar Pengetahuan Ergonomi dan Aplikasi di Tempat Kerja, Surakarta: Harapan Press.

Zainal, A., et., al. (2016). Pengaruh Beban Kerja dan Kompensasi Terhadap Komitmen Organisasional Dalam Upaya Meningkatkan Kinerja Karyawan (Studi pada Karyawan Tingkat Pelaksana Perum Jasa Tirta I Wilayah Sungai Brantas dan Bengawan Solo). Jurnal Bisnis dan Manajemen, 3(2). 